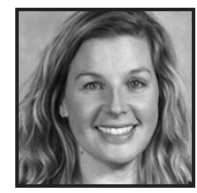

\title{
"It's More Like What You Think of Land": Bringing Together Community and Education Through Mapping
}

Susan Jagger, Ryerson University

\section{ABSTRACT}

Community mapping projects involve citizens in the creation of maps that communicate local knowledge, relationships, and visions. The power in community mapping emerges from the process of creating the maps themselves. By exchanging and reflecting upon ideas, stories, and understandings of place, mapmakers develop and strengthen their connections to their communities. This paper explores grade four students' experience of a community mapping project as it shares the stories and understandings of four participating students. Their narratives illustrate how community mapping can inform students' understanding of their community, foster and strengthen their community connections, and influence their perceived place within their community.

\section{Mapping as a Means of Educating the Community About the Community}

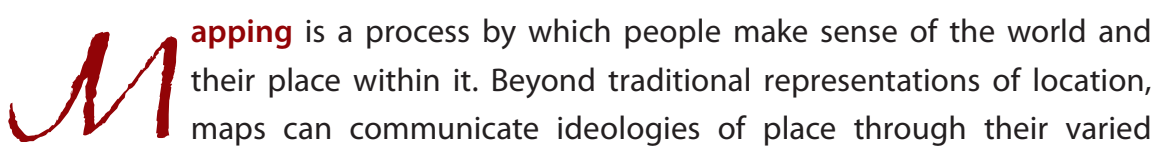
signs, symbols, and forms. One form, the community map, reflects the shared spaces, knowledge, and values of members of the community. Perkins (2008) defined community mapping as "local mapping, produced collaboratively, by local people and often incorporating alternative local knowledge" (p. 154). Based on shared lived 
experiences, it centres on those features that people value and the visions that they hold for the future of their community. "It requires people to dig into the past, to walk their local territories and streets, and to talk to their neighbours" (Lydon, 2003, p. 22). Created maps can take on a range of forms, from traditional topographic maps to more artistic and organic representations, for example, created postcards, shared anecdotes of situated experiences, and renaming of paint chip colors and general terms to place-specific names (Hurren, 2008), and using a multitude of materials including textiles, paint, sculpture, written word, drama, film, photography, and song (Clifford \& King, 1996).

Community mapwork has been used to identify and communicate supportive resources and services in the community for children, families, and students (see, for example, Connor, 2001; Robinson, Vineyard, \& Reagor, 2004; Tindle, Leconte, Buchanan, \& Taymans, 2005). Most prior community mapping projects have focused on informing humans of local services and resources of benefit to them and do not fully embrace in their maps the community as a collective of biotic and abiotic members-Aldo Leopold's (1966) community as "soils, waters, plants, and animals, or collectively, the land" (p. 239). One example of community mapping that does embrace the inclusion of the natural world in community is the Parish Map Project. Organized by Common Ground in the United Kingdom, the project was a means for people to come together and share what they cherished about their community: wildlife, history, landmarks, people, festivals, and stories (Clifford \& King, 1996).

Not only do community maps reflect those community features of importance to citizens, but the actual process of creating the maps is also a means of empowering community members and giving them a voice in their place. Historically, mapping has been an exclusive tool of the affluent; community mapping opens up cartographic expression to all citizens including women, children, minority groups, and other marginalized people. As noted by Lydon (2003), community mapping "is the antithesis of expert-led discourse and development as everyone's views matter and can only enhance the map" (p. 12). Community mapping has the potential to stimulate social and procedural change through increased awareness and knowledge of local concerns and issues (Parker, 2006). Most community mapping does, in fact, seek to encourage change and the maps themselves are used in the process (Perkins, 2007). Positive changes have been successfully realized following community mapping projects in, for example, the securing of conservation areas in Thailand, restoring an abandoned stream park in Victoria, BC, and creating a more sustainable community in Portland, Oregon (Parker, 2006). Similarly, First Nations communities have used community maps to help sustain traditional knowledge and ways of living (Lydon, 2003). 
The reach of community mapping can be extended with the inclusion of children in the mapping process. Lydon (2003) asserts that children's participation is critical as they see places in different ways. The engagement of children in community mapping work can be easily realized in the $\mathrm{K}-12$ curriculum and instruction as a curricular foundation or a complement to existing themes and learning objectives. In its content, processes, and products, community mapping is inherently crosscurricular and allow for the construction and communication of situated knowledge, application of understandings, and experience of rich learning contexts beyond the school. Community mapping is an inclusive pedagogical approach because all students can contribute and all their contributions are valued and add to the map's importance. Despite the benefits of these ecologically inclusive projects and the potential for local mapwork to be incorporated across the curriculum, there has been a lack of research on how students' participation in community mapping influences their perceptions and understandings of their communities and their developing views and ideas about the environment and their place within it. This paper begins to chart this void as it focuses on four students' community mapping experience and how that experience informed their understanding of, fostered connections to, and influenced their perceived place in their community.

\section{The Sandy Beach Mapping Project and Notes on the Research Method}

This study followed a British Columbian grade four class in its participation in a three-month long community mapping project of Sandy Beach, a popular local provincial park. The mapping project focused on a number of aspects of Sandy Beach: 1) local history; 2) natural history and ecosystems; 3) First Nations' connections to and uses of the land; and 4) personal connections to and special places at the park. Students visited the park on three field trips and had school visits from the local museum director and the school's First Nations liaison teacher. The class worked on mapping activities once or twice per week over the course of the project.

The project began with an introduction to what mapping is, what maps can communicate, and what might be included on maps. After creating some maps of familiar places at school and home (i.e., classroom, playground), students made maps of Sandy Beach that included photography, storytelling, illustrations, poetry writing, and sculpture, and thematically connected to our field trips to the park. Our major mapping activities were the collaborative creation of an emergent bulletin board 
map (Sobel, 1998) of Sandy Beach, sculptures of special places at the park (Figure 1), and a class book that compiled students' letters written to someone who has not been to the park. These letters were modeled on Sheryl McFarlane's Jessie's Island (1992).

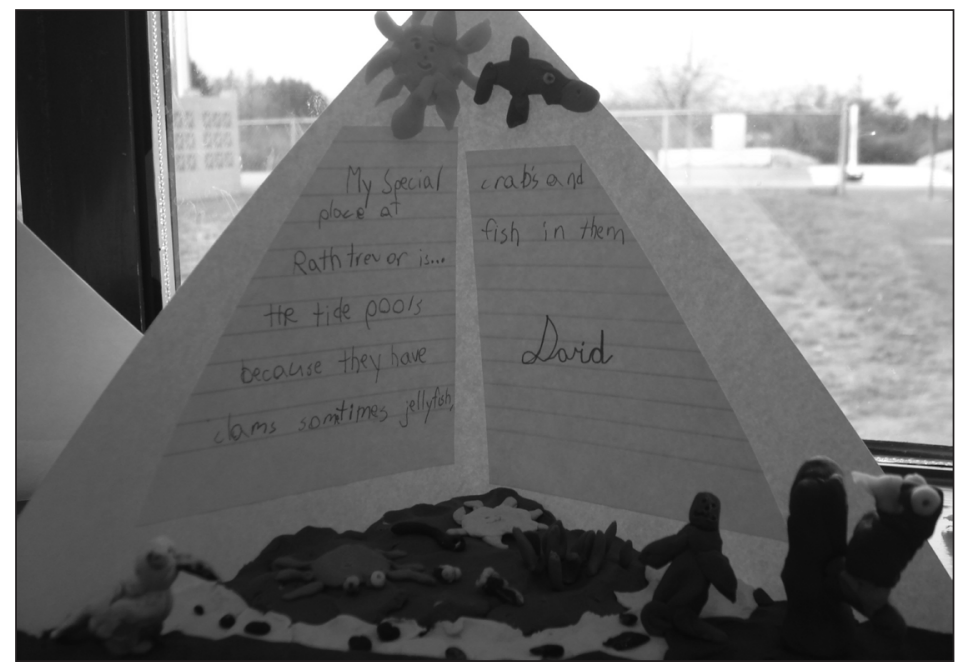

Fig. 1: Example of special place sculpture

Data was collected and analyzed through the duration of the project. Observations and field notes were taken on each mapping session, field trip, and presentation. Students participated in two small group semi-structured interviews, the first immediately after the end of the project and a second follow-up interview three and a half months later. Samples of student mapwork and photographs of artifacts and activities were also collected. While analyzing the collated data, I was struck by the experiences and ideas shared by four students: Charles, Ethan, Norah, and Xavier. The data collected from all students revealed their unique project-related understandings of Sandy Beach and the environment, but these four students shared narratives about the park and the environment more broadly that were particularly poignant, and ranged from positive and encouraging words to negative and pessimistic views. Themes that were common across their understandings and experiences of the community mapping project-diversity and relationships, personal connections and stories, and care and the communityare discussed below. Charles, Ethan, Norah, and Xavier's mapping stories are shared as created composite interviews with interjecting discussions. The text includes extended direct quotes from my interviews with the students as well as paraphrasing of some points of discussion resulting in the following text. As with community 
mapping itself, the voices and ideas of mapmakers are central and this is why I chose to include significant blocks of quoted text in their own words.

\section{Norah: "It's a good place...to get the idea of what the world should be like"}

Norah is a quirky and inquisitive nine-year-old. She has a few close friends, but is sometimes an outsider in her class. Norah is a very sensitive and emotional girl; she is passionate about local environmental issues. She is interested in natural history and has a rich understanding of animals and plants gained from her learning at school and at home with her family. Norah is a great storyteller and she likes to share her experiences in places and with people.

$\mathrm{S}^{2}$

$\mathrm{N}$

S

$\mathrm{N}$

$\mathrm{S}$

$\mathrm{N}$

S

$\mathrm{N}$
Last night I went to Sandy Beach with my sister and we saw these two huge owls up in a tree at the far end of the park where the big Arbutus tree is.

What color were they?

It was difficult to see-it was getting dark. They had ears though.

Those were great horned owls.

I think you're right.

There is a family of great horned owls that live in my backyard. They had a chick.

How cool to see that and watch the chick grow! My sister and I were watching this pair of owls and when they hooted, they tilted forward and lifted their tail feathers.

I think that is actually a warning. They are pretty shy.

A lot of different animals live at Sandy Beach.

Tons! Most live in the forest. We saw a caterpillar that didn't have any hair. I saw deer tracks and deer poop so I know there are deer at Sandy Beach. I've seen them there before too. We saw woodpecker holes in trees but no woodpeckers at the holes. Now they have spiders' nests in them. I guess the spider moves in and then the woodpecker gets the food.

The woodpeckers eat the spiders?

I think so. Then there's jellyfish, the lion's mane thing, whatever it is. When they're in the water, they're smaller but when they are on the 
land, they just push their bodies out. And shrimp. I remember going to Sandy Beach with my mom and there was a little shrimp that was washed up on the shore trying to get back into a tide pool. I called him Bob. There are sea cucumbers and moon snails and red rock crabs. My group saw a king crab. It was sort of getting dried up because of the sun and it was far away from the tide pool. And so, Rachel offered her hat so we put him in her hat and threw him in a tide pool. We checked on him later and he was eating the other rock crabs. Crabs sometimes eat seastars. I found a tiny one in a tide pool once. I don't know much about seastars.

Norah has a rich understanding of the diversity of life at Sandy Beach. She is able to identify many different kinds of life including many types of animals both by viewing the animal itself and also by looking at signs of their presence. For example, she knows that deer live in the park because she has seen deer tracks and scat. Furthermore, Norah is able to identify animals that live in the park, such as the great horned owls, by their features and behaviours. Norah's taxonomic knowledge of animals living in the park is also evident as she refers to them by specific names (e.g., moon snail rather than snail).

Norah's conversation with me alludes to her knowledge of the interconnectedness of species living together in the community. She recalls seeing holes made by woodpeckers in trees at Sandy Beach and that the holes were home to spiders' nests. She then speculates that the spiders are also a food source for those woodpeckers. ${ }^{3}$ Norah's understanding of relationships in ecosystems extends to those between living and non-living things. For example, she talks about coming across a crab on the beach that is drying in the sunshine away from the safety of a tide pool so she and her friends "save" it by returning it to water.

I remember collecting sand dollars at Sandy Beach when I was a little girl. There were thousands there then, but now there aren't nearly as many.

$\mathrm{N} \quad$ If they are black, they are alive and if they are brown, they are dying and if they are white, they are dead. There were lots of wasps ${ }^{4}$ there in 
the fall. I remember that Ethan said he felt something on his hair, it was a wasp on his hair and it stung him on the head, and then flew away and up Xavier's shirt and stung him on the back. And then a swarm of wasps came over and everyone was screaming. Jack hit one with his walking stick like it was a golf club and it stopped right in front of me with one wing bent and it just stared at me like, "Hi." He didn't sting me. I was just lucky. I know they made the wasps angry.

Oh my goodness, I remember that day. Poor Ethan and Xavier!

I went to Sandy Beach over spring break and we saw some eagles and when we went on the beach, I didn't really know that they were eggs because it looked like sand.

Eggs?

$\mathrm{N}$

We were walking on thousands and thousands of fish eggs. I guess we killed them all. Oops.

You have a lot of memories of animals at Sandy Beach.

Plants and mushrooms too. I saw salmonberries and skunk cabbage. And I saw those red mushrooms with the white dots on them. There was the dragon tree too. It's fun to climb on. The area that looks like a neck, it's all mossy and there's a little tree growing out of it. I called him Fluffy.

This interview excerpt shares only some of the personal stories at Sandy Beach that Norah told me over the course of the mapping project. She happily shared the story of her group of students coming across several angry wasps at the park, noting that she was not bothered by the wasps. She said that one even stopped mid-flight, looked at her, and seemed to say hello. Like the wasp, Norah anthropomorphizes many non-human things at the park. Notably, she also names a large tree, Fluffy. The tree, which is much loved by the students, is called by several names including the dragon tree and dinosaur tree (see Figure 2). Norah's relationships with members of the Sandy Beach environmental community are almost like friendships and for her, time spent at Sandy Beach is time spent with friends. 


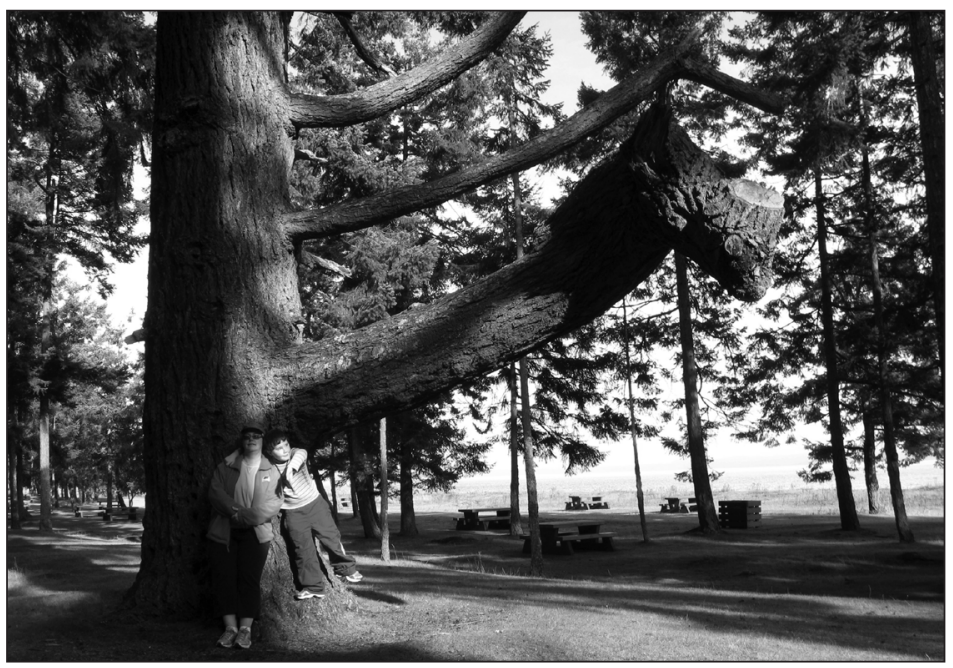

Fig. 2: The dragon, or dinosaur, tree

Norah's words show her recognition of the impact of her actions on the Sandy Beach community and its members. She voiced her realization that she was stepping on countless fish eggs on one visit and had killed many potentially viable juvenile fish. As we will next see, Norah's understanding of the human impact on the broader environment is very strong and passionate.

It sounds like Sandy Beach is a pretty special place with lots of stories. Sandy Beach has a lot of history. It hardly has any high-tech stuff or anything. It makes you feel nature friendly, like the world's not going to end from global warming. It's a fun place to go and it's a good place if you're trying to be environmentally friendly, to get the idea of what the world should be like. It's just a nice place. The only thing I don't like is there's no indoor plumbing. Sandy Beach is a place that gives you hope?

Yes. Sometimes I get so angry that people just don't care. What I really don't like is people making animals extinct. If people kill one thing, eventually we'll all go "Poof!" Either that or the world will just be a big garbage dump. Sometimes I actually think that it's all right. I really think that the world would be a better place without humans. 
Some people think that humans deserve to live more than the entire place where we actually are. I think the worst part about global warming and pollution and stuff like that is that nobody's really doing anything about it.

What do you think we should be doing?

$\mathrm{N}$

Pick up garbage, ride a bike, buy energy-efficient cars, switch to solar power. Stop logging in Cedar Forest. It's killing owls and trees. The only remaining spotted owls are on Vancouver Island and they're becoming more extinct because of logging. The great horned owls in my backyard moved there because there's hardly any traffic on my street and there's a very large supply of rodents and bugs in the woods nearby.

Norah has very definite opinions on humans' treatment of living things and ecosystems. When considering the whole world, Norah's outlook is bleak and she tends to take a doom-and-gloom view, even stating that she thinks that the world would be a better place without humans. Perhaps the scale of global environmental problems is overwhelming for her and she feels the fear and frustration that many of us do (Sobel, 1996). Her comments also speak to the rights of nature that she recognizes and that the place where we live, our community, deserves life as much as humans do. These rights of place recall Aldo Leopold's land ethic and shift of humans' role from conqueror of the land to equal member and citizen of the land community (Leopold, 1966).

Norah speaks more positively and optimistically when she talks about Sandy Beach and the local environmental community. It is a place of hope for her. She says that Sandy Beach is what the world should be like, and it is a nice place to spend time. Norah puts forward a number of feasible ways to care for the environment. It seems that while on a large scale Norah is doubtful of our environmental future, she sees that her actions and those of others can make a difference in the community. 


\section{Charles, Ethan, and Xavier: "[It] feels more like home"}

Charles is an outgoing, and often outspoken, grade four student. He is very well liked by his peers and has many friends in the class. Academically, Charles is challenged by content covered in class. He has difficulty staying focused in the classroom and this can make learning in the school setting very difficult for him. Charles has many unique connections to Sandy Beach and he readily shares stories of generations of his family spending time there. His many visits to Sandy Beach have helped to make its geography and biology very familiar to him.

Ethan is a very bright, mature, and thoughtful nine-year-old. He has a small group of close friends and is well liked by all his classmates. Ethan is strong academically and is an incredibly hard worker; he is dedicated and diligent. He regularly offers insightful contributions to class discussions. Ethan has a very supportive family that is actively involved in the school community. His mother accompanied us on our mapping field trips to Sandy Beach and regularly volunteers in the classroom and school. Ethan and his family spend a lot of time together, often going on walks at Sandy Beach.

Xavier is a very energetic and talkative boy. He has many friends in class and is always keen to entertain them. While he asks a lot of questions about those topics that interest him, Xavier struggles academically and his seemingly endless energy can make it challenging for him to stay on task in class. He has difficulty sitting for very long and because of this he is often singled out in class for his disruptive behaviour.

$\mathrm{S}$

$\mathrm{X}$

$\mathrm{E}$

We did a lot of things at Sandy Beach when we worked on our mapping project. Tell me about the things that we saw and what we did.

The sticky ball tree!

The smoker tree.

Squirrels, puffballs.

Pileated woodpecker, fish, crabs... hermit crabs. Jellyfish.

Alive and dead ones.

There were lots of ants and ant trails. It was like a little war ditch. War ditch?

You know like in World War I they go in a trench. OK, that's a good way of describing it. 
I saw crab trails on the beach. It looks like three dots beside each other and it just keeps going. I followed one and found a crab underneath a rock.

The wasps. There's a zone almost where the wasps are. The attack zone.

Yeah, the first time, oh my god, was it full of bees!

Wasps! They were everywhere! I got hit by the wasps, I got the worst. Every field trip I go on I get hurt.

I think that from the first time we were there to the second time, there was less bees and the third time, there was none. And I'm not even sure if that was between the seasons because it was just the middle of fall. I would say they would have started, I would say the bees would start to go into their nests a bit later, even from that third time.

Bees are a good thing, they pollinate flowers.

Like Norah, Charles, Ethan, and Xavier have a thorough understanding of the plant and animal life and behaviour at Sandy Beach. They easily list off several species they recall from park visits and while not all species are known by their general names, specific organisms are identified using created names that were used by all the students (i.e., smoker tree, sticky ball tree). The boys also detail unique tracks and products of different types of animals. For example, Charles described paths made by ants as being like war ditches or trenches and Xavier clearly details the trail left on the sand by a sidestepping crab. Without prompting, Xavier embraced Sobel's (1996) call for children to be engaged in explorations of their community by following paths and trails, here the tracks left by, and leading to, a crab. Also as Norah did, the boys shared an enthusiastic recollection of their run-in with wasps at the park; Ethan went so far as to label the part of the park where the wasps were as "the attack zone." He was also mindful of the changes that took place over time to the wasp population. He noticed that the number of wasps went down with each visit to the park, from late summer to fall, and speculated that this was because they were going into their nests for winter. Despite being stung several times, Xavier noted that bees were helpful as pollinators and had an important role in the ecosystem at Sandy Beach. These shared details provide an insight into their understandings of the diversity of life and behaviours at Sandy Beach. 


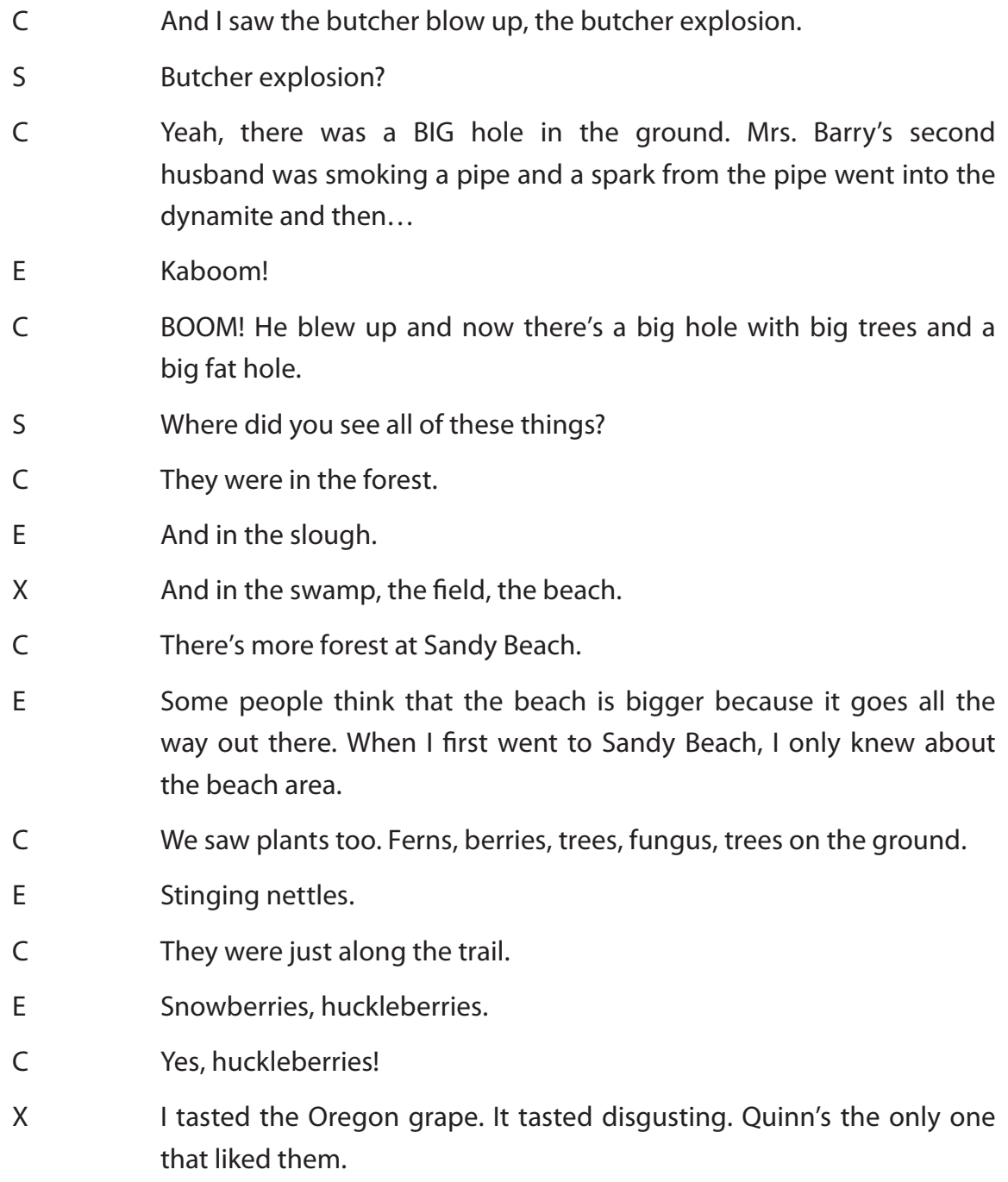

The local museum director's presentation of Sandy Beach history to the class was very engaging; the students most enjoyed hearing about the demise of Mrs. Barry's ${ }^{5}$ second husband. As Charles was exploring at Sandy Beach and came across a large hole in the ground, he assumed that it must have been where the explosion occurred. While this was unlikely, Charles was relating the local history to the landscape of the park. Ethan also made connections, but to his own history, as he noted that on his 
first park visit, he thought it was mostly beach. Now though, after many explorations, he knows that Sandy Beach is largely forested.

In their mapping of Sandy Beach, students were encouraged to use all their senses. Most memorable for many was tasting the berries that grew at the park. Students sampled blackberries, salal berries, and lots of huckleberries and some even tasted the bitterness of Oregon grape. Ethan and Charles also distinctly remembered the stinging nettles and where they were. It is likely that their sensory experience of the nettles, albeit unpleasant, like the sting of the wasps, helped them to remember those parts of the environmental community at Sandy Beach.

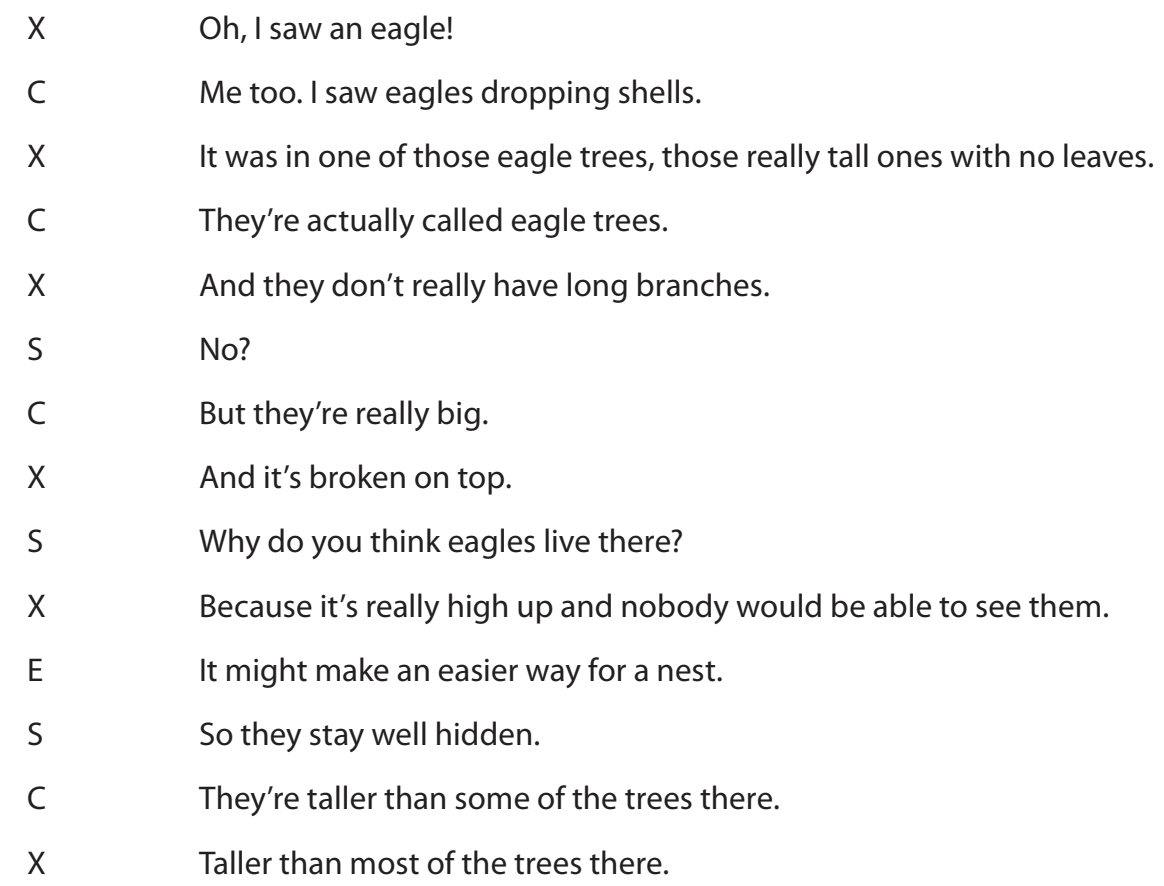

Eagles are very common at Sandy Beach and they live high in the trees framing the beach. As Charles, Ethan, and Xavier discussed eagles at the park, they described where they nest and why. The boys stated that eagles live and nest in the very tall trees in the park, those without branches and that seem to be broken at the top, 
because these spots are very high up and therefore they cannot be seen and are able to stay hidden. Ethan also thought that it might be easier for eagles to nest in very tall trees. In their discussion, the boys were able to apply what they had learned in the classroom about animal adaptations to what they had seen first-hand at Sandy Beach. They could see how animals used their surroundings to meet their basic needs, here eagles using the trees for safe nesting sites.

Hey, the dino tree! My entire family calls it the dino tree.

Your dragon tree's safe.

The dinosaur tree is my favorite part of the park. It's kind of, like, alive, like the guardian of the forest. You know how trees make you feel a little bit more safe?

Why do you think the trees make us feel safer?

Because it might be old instincts because back when we didn't have metal, we didn't have tables.

We didn't have roads.

We all used wood for most things and I guess we just feel safe because the trees have helped us so much. I know that First Nations used to build most of their buildings and crafts and especially canoes from cedar.

So they protect us and take care of us.

Yes. The deeper I get into the woods, the safer I feel.

The whole park is my favorite part. It's always nice being there. It gives me good thoughts and brings back memories. A couple of kilometres down, my mom and dad got married in the church down there. My grandma lives right next to Sandy Beach. And we have the Terry Fox Run there.

Animals use the park more than anyone. They use it for food, shelter, homes. And there's a playground for people and also there's a playground there for animals. Just in the woods.

I think people have just taken over. lan's mom said, "Enjoy the park how it is" and I kind of agreed with her because there's less things there. Sandy Beach is way better than Seaside. 


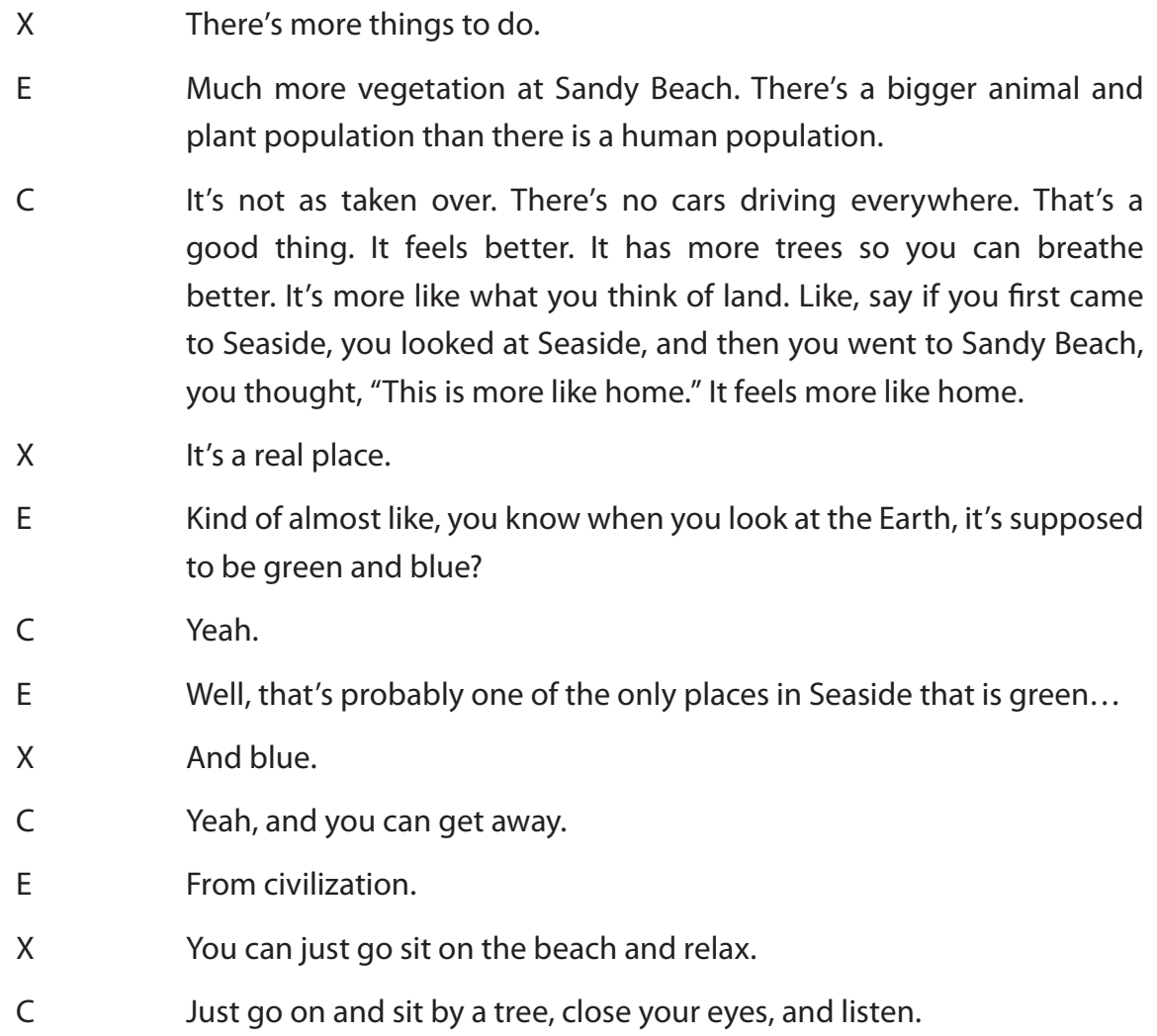

While they did not anthropomorphize plants and animals like Norah did, Charles, Ethan, and Xavier used created names to refer to organisms that they observed on field trips and continued to use these names well after the visits. Ethan spoke about the dinosaur tree, a large tree near the beach that, with a little imagination, looked ike an animal with a very long neck. Perhaps it was in part because it looked like a dinosaur or dragon that Ethan felt that it was a guardian of the forest.

The boys agreed that Sandy Beach felt safer than the rest of their community. Ethan felt protected by the trees and thought this might have been because of the ways that trees help us in everyday life, both now and historically. Along with feeling safe at Sandy Beach, Charles, Ethan, and Xavier identified Sandy Beach as a place of refuge. It was relaxing for them and afforded them an escape from daily life. With more plants and animals and fewer cars, Sandy Beach was a place where they could get away from the outside world. It was also a place of play for humans and, 
according to Ethan, for animals. These feelings mirrored those expressed by Norah. To the students, the park was a place where they felt at peace. It was like home.

Like Norah, the boys described Sandy Beach as an ideal place, as what the world should be like. This ideal is a place with biodiversity, many plants and animals, and of varied scapes of land and water, green and blue. To Charles, "it is more like what [he thinks] of land." This perception is analogous to Leopold's (1966) land ethic as it extends the land and community, and what is valued in the community, to include plants, animals, soils, and waters. Taken together in discussion, the boys' ideas and assertions allow them to construct a rich ecological and inclusive understanding of Sandy Beach and the community, and to listen to the community through their experience of the park.

\section{Community Mapping as a Bringing Together of Community and Education}

In this project, community mapping took education out of the school and embedded it within the community. Participating students experienced situated curriculum and pedagogy beyond prescribed objectives and outcomes, and allowed students to come to know the community that they are inherently a part of. The mapping process opened up the community, and the concept of community itself, to students' unique ways of knowing the natural world.

Students recognized the diversity of life at Sandy Beach. They knew many species of plants and animals at the park, both by specific names and students' created names. Sobel (1996) encourages this informal yet personal naming of living things as a way for children to come to know and make connections with the natural world before formalizing understandings. Students were also able to easily describe and explain animal behaviours that they observed. Not only do students appreciate the biodiversity at the park, but they are also aware of the interconnectedness of life at Sandy Beach. They recognize the ways that biotic and abiotic elements work together to support each other and the community. It is interesting to note that the students already see themselves as part of the environment and that their presence in, and absence from, the park affects the health and balance of the community and community members. 
The students' understandings of Sandy Beach ecology were supported by their personal experiences and connections to the park. Their stories shared meaningful learning in the community, both during the mapping project and also with family and friends outside of school. These shared experiences allowed students to develop situated understandings of the community through their interactions with their peers and with place. Students were forming and strengthening their own relationships with the community and this supported their ecological understandings. The experiences in the natural world were memorable and meaningful, and this is important in fostering positive environmental attitudes and actions in adulthood (Chawla, 1999). As simply and eloquently asserted by John Burroughs (1919), "Knowledge without love will not stick. But if love comes first, knowledge is sure to follow." Students' personal relationships with the community were ones of understanding and care.

This relationship of care is reciprocal and the students' experiences of Sandy Beach share that the environmental community cares for them. Their comments clearly identify the park as a positive place to spend time. Students' feelings that they could escape from civilization and relax while at the park parallel the extensive research on the restorative effect of natural spaces (see, for example, Kaplan, 2001; Kaplan \& Kaplan, 1989; Wells \& Evans, 2003). For students, this positive relationship with the park is immediately beneficial to them and looking forward could be a key experience leading to deeper connections to and actions in the environmental community (Ewert, Place, \& Sibthorp, 2005; Wells \& Lekies, 2006), allowing them to reciprocate in the relationship of care with the community.

The students have an idea of what the environmental community should be like-Sandy Beach. The park was viewed as somewhat of a benchmark against which other places could be measured. Their perceptions are interesting because Sandy Beach is a park in which the presence of humans is obvious and their role in shaping the immediate environment is clear. It is possible that the students' affection for the park leads them to set it apart. Sandy Beach could also be the most pristine natural setting that many students have experienced. Seeing the park as "a real place" could encourage students to respect it and other natural communities through mindful decisions and actions. This is in contrast to the doom-and-gloom images we often see of environmental issues and the fear and helpless that these can induce (Sobel, 1996). Having experienced "what the world should be like" might also illuminate for students those dramatic changes made by humans to other environmental communities and encourage them to care for all communities. 
Community mapping projects can open up to mapmakers a space for learning about, relating to, and caring for their community. For students and teachers, education is taken out of the school and firmly situated within the content and context of their community. Along with giving voice to citizens, community mapping allows for those unique understandings for place to be validated and communicated. And through its processes and products, community mapping invites the community to look forward to possibilities and potentials, for visions of what home might look like and to take action together, as a community, to realize those shared goals.

\section{Acknowledgment}

This research was partially funded by the National Science and Engineering Research Council, Canada's Pacific CRYSTAL for Scientific and Technological Literacy.

\section{Notes}

1. All names of students and places used are pseudonyms to protect the anonymity of participants.

2. $\mathrm{S}, \mathrm{N}, \mathrm{C}, \mathrm{E}$, and $\mathrm{X}$ identify the speakers Susan, Norah, Charles, Ethan, and Xavier respectively.

3. Woodpeckers are omnivorous and eat plants (fruits, nuts, berries) and animals (usually insects living in decaying wood).

4. Students used the terms wasps and bees interchangeably to refer to wasps.

5. The Barry family established a farm on the land at Sandy Beach in the early 1900 s. In the 1960s, Sandy Beach became a provincial park. 


\section{References}

Burroughs, J. (1919). Field and study. Cambridge, MA: Riverside Press.

Chawla, L. (1999). Life paths into effective environmental action. Journal of Environmental Education, 31(1), 15-26.

Clifford, S., \& King, A. (Eds.). (1996). From place to PLACE: Maps and Parish maps. London: Common Ground.

Connor, S. (2001). Using community mapping to enhance child development. Education Canada, 40(4), 24-26.

Ewert, A., Place, G., \& Sibthorp, J. (2005). Early-life outdoor experiences and an individual's environmental attitudes. Leisure Sciences, 27, 225-239.

Hurren, W. (2008, May). Mapwork (A component of postcartographica). Exhibition of photography and mixed media. Victoria, BC: Xchanges Gallery.

Kaplan, R. (2001). The nature of the view from home: Psychological benefits. Environment and Behaviour, 33(4), 507-542.

Kaplan, R., \& Kaplan, S. (1989). The experience of nature: A psychological perspective. New York: Cambridge University Press.

Leopold, A. (1966). A Sand County almanac with essays on conservation from Round River. New York: Ballantine Books.

Lydon, M. (2003). Community mapping: The recovery (and discovery) of our common ground. Geomatica, 57. Retrieved from http://mapping.uvic.ca/sites/mapping.uvic. ca/files/lydon_cartographica_2003.pdf

Lydon, M. (2007). Mapping our common ground: A community and green mapping resource guide. Victoria, BC: Common Ground.

Manoli, C., Johnson, B., \& Dunlap, R. (2007). Assessing children's environmental worldviews: Modifying and validating the New Ecological Paradigm Scale for use with children. Journal of Environmental Education, 38(4), 3-13.
McFarlane, S. (1992). Jessie's island. Victoria, BC: Orca Book Publishers.

Parker, B. (2006). Constructing community through maps? Power and praxis in community mapping. The Professional Geographer, 58(4), 470-484.

Perkins, C. (2007). Community mapping. The Cartographic Journal, 44(2), 127-137.

Perkins, C. (2008). Cultures of map use. The Cartographic Journal, 45(2), 150-158.

Robinson, C., Vineyard, M., \& Reagor, J. (2004). Using community mapping in human ecology. Journal of Family and Consumer Sciences, 96(4), 52-54.

Sobel, D. (1996). Beyond ecophobia: Reclaiming the heart in nature education. Great Barrington, MA: Orion Society.

Sobel, D. (1998). Mapmaking with children: Sense of place education for the elementary years. Portsmouth, $\mathrm{NH}$ : Heinemann.

Tindle, K., Leconte, P., Buchanan, L., \& Taymans, J. (2005). Transitions planning: Community mapping as a tool for teachers and students. Improving Secondary Education and Transition Services Through Research, 4(1), 1-5.

Wells, N.M., \& Evans, G.W. (2003). "Nearby nature: A buffer of life stress among rural children." Environment and Behavior, 35(3), 311-330.

Wells, N., \& Lekies, K. (2006). Nature and the life course: Pathways from childhood nature experiences to adult environmentalism. Children, Youth, and Environments, 16(1), $1-24$. 


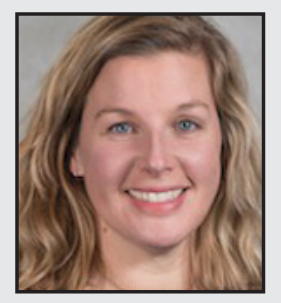

Susan Jagger is an Assistant Professor in the School of Early Childhood Studies at Ryerson University and has many years of elementary school teaching experience in British Columbia and in the United Kingdom. Her research interests include: environmental education, learning gardens, community mapping, poststructuralism and deconstruction, informal learning, science education, children's participation, participatory research, and arts-based research approaches. Currently she is working with and in an urban elementary school community to explore the strengths and challenges of urban school gardening, map children's evolving environmental attitudes and actions, and engage children as researchers of their own school garden experience. 